\title{
BuSINESS AND HUMAN RIGHTS - IMPLEMENTING THE UNITED NATIONS \\ GUIDING PRINCIPLES ON BUSINESS AND HuMAN RightS IN SLOVENIA
}

\section{Accepted \\ 31. 5. 2020 \\ Revised \\ 9. 6.2020 \\ Published \\ 22. 6. 2020}

UDC

$658+342.7: 341.123(497.4)$

Keywords

human

rights,

business,

due diligence,

state-owned

enterprises,

national

action

plan on

business and

human

rights.

\author{
TIL ROZMAN \\ University of Ljubljana, Faculty of Social Sciences, Ljubljana, Slovenia; e-mail: \\ til.rozman@fdv.uni-lj.si \\ CORRESPONDING AUTHOR \\ til.rozman@fdv.uni-lj.si
}

Abstract Business enterprises have an independent responsibility to respect human rights. United Nations Guiding Principles on Business and Human Rights provides global standard for preventing and addressing the risk of adverse impacts on human rights linked to business activities. This paper builds on the finding that Republic of Slovenia is one of the few countries that have adopted national action plan on business and human rights. Paper further argues that state-owned enterprises should play key role in promoting, respecting and protecting human rights in business. Slovenian state has capital investments in a number of major companies, therefore, its responsibility for protection of human rights in business is even greater. After analyzing Slovenian national action plan on business and human rights, paper focuses on its implementation in the Slovenian business practices. It is argued that all Slovenian state-owned enterprises should explicitly commit to respect human rights in business and to prevent possible negative impacts on human rights as stateowned enterprises should lead by example. Furthermore, such commitment of the Slovenian state-owned enterprises would be in accordance with the concept corporate human rights due diligence which is expected to become mandatory in the EU in the near future. 


\section{$1 \quad$ Introduction}

Business enterprises' binding obligations to respect human rights stem primarily from domestic legislation. Despite significant efforts by the international community, the United Nations International Treaty on Business and Human Rights has yet to be adopted and it seems questionable whether adoption of either that treaty or an alternative international legally binding instrument aiming at regulating activities of transnational corporations and other business enterprises in the field of human rights is realistic in the near future. One of the obstacles is the resistance of many states to the adoption of an international treaty creating direct human rights obligations for corporations instead of a more classical and traditional view that only states are subjects of international law and, consequently, only states are in a position to bear international obligations (Bernaz, 2018). In many areas of law, e.g. criminal liability and environmental civil liability, individuals are capable of being subject to international prosecution and to bear international obligations. Therefore, it does not seem convincing and coherent to argue that business enterprises cannot be regulated by international treaties. In the absence of a binding international treaty, however, a variety of quasi-legal documents list quasi-legal types of international obligations on business and human rights. The most authoritative legal document on business and human rights is the Guiding Principles on Business and Human Rights: Implementing the United Nations "Protect, Respect and Remedy" Framework (hereinafter: Guiding Principles).

The United Nations Human Rights Council adopted Resolution 17/4 of 16 June 2011 on Human Rights and Transnational Corporations and Other Business Enterprises. ${ }^{1}$ The Resolution endorsed, inter alia, the Guiding Principles, and established a Working Group on the issue of human rights and transnational corporations and other business enterprises. The Working Group encouraged all states to adopt national action plans on business and human rights as part of their responsibility to disseminate and implement the Guiding Principles.

\footnotetext{
${ }^{1}$ https://documents-ddsny.un.org/doc/RESOLUTION/GEN/G11/144/71/PDF/G1114471.pdf?OpenElement (accessed: 31. 5. 2020).
} 
The Republic of Slovenia is one of the 23 states that has adopted a national action plan on business and human rights. ${ }^{2}$ The fundamental aim of the Slovenian national action plan (hereinafter NAP) is to ensure that the Guiding Principles - as a set of guidelines that apply to all states and to all business enterprises - are implemented in practice.

The Guiding Principles provide a globally recognized framework for protection against human rights abuses committed in business operations. The Guiding Principles set forth three main pillars. The first is the state's duty to protect human rights. The second is the corporate responsibility to respect human rights The third pillar concerns access to effective remedies. Accordingly, NAP follows this framework, especially in the chapters dealing with the state's duty to protect human rights (2.1.) and in the chapter on access to remedies (2.2.). Furthermore, NAP outlines Slovenia's priorities (2.3.), its expectations towards business enterprise (2.4.) and provides guidelines on corporate human rights due diligence. Corporate human rights due diligence constitutes the core instrument for identifying, preventing, mitigating and accounting for how business enterprises address their adverse impact on human rights, chapter 3 focuses on this instrument. It explains what corporate human rights due diligence is and its significance (3.1.), lists some of the emerging good practices for conducting corporate human rights due diligence (3.2.), explains the most important drivers of corporate human rights due diligence (3.3.) and ends with a discussion of the NAP Guidelines on Corporate Human Rights Due Diligence (3.4.).

In general, state-owned enterprises play the leading role among all business enterprises in respecting human rights. Since the Republic of Slovenia has capital investments in a number of major Slovenian companies, it plays a pronounced role in the process of respecting human rights. Therefore, chapter 4 deals with the issues of implementation of the Guiding Principles in the business practices of Slovenian state-owned enterprises (4.1.), with the commitment of the Slovenian companies to respect human rights in business and to prevent possible negative impacts on human rights (4.2.) and proposals moving forward (4.3.).

\footnotetext{
${ }^{2}$ In addition to the Republic Slovenia, State national action plans on Business and Human Rights has been adopted by the United Kingdom, The Netherlands, Denmark, Finland, Lithuania, Sweden, Norway, Colombia, Switzerland, Italy, United States of America, Germany, France, Poland, Spain, Belgium, Chile, Czech Republic, Ireland, Luxembourg, Kenya and Thailand, https://www.ohchr.org/EN/Issues/Business/Pages/NationalActionPlans.aspx (accessed: 31. 5. 2020).
} 
Chapter 5 concludes that state-owned enterprises should lead by example. However, in the absence of international binding law on business and human rights, it is of paramount importance that national legislation fills this void. There are already some examples of mandatory corporate human rights due diligence legislation in EU Member States and the European Commission has committed to propose mandatory corporate due diligence legislation in 2021.

\section{Implementing Guiding Principles through NAP}

\subsection{The State duty to protect human rights}

Guiding Principles' chapter on the state's duty to protect human rights lists two foundational principles and they are both literally transposed into NAP.

The first foundational principle reads as follows:

"States must protect against human rights abuse within their territory and/orjurisdiction by third parties, including business enterprises. This requires taking appropriate steps to prevent, investigate, punish and redress such abuse through effective policies, legislation, regulations and adjudication." 3

This principle highlights the state's fundamental obligation under international human rights law, namely to respect, protect and fulfil the human rights of individuals within the state's territory and/or jurisdiction, including the duty to protect against human rights abuse by business enterprises or other third parties.

The second foundational principle reads as follows:

"States should set out clearly the expectation that all business enterprises domiciled in their territory and/ or jurisdiction respect human rights throughout their operations." "4

${ }^{3}$ Guiding Principles, p. 3.

${ }^{4}$ Guiding Principles, p. 3; NAP, p. 10. 
This principle requires the state to explicitly and unambiguously express its expectation that all business enterprises respect human rights not only within the state's territory and/or jurisdiction but also throughout their extraterritorial activities. As explained in NAP, specific expectations concerning human rights protection in business are defined in the relevant legislation governing corporate liability for damages, ownership relations, consumer protection, the fight against corruption, privacy protection, employment relationships, health protection, environmental protection, and prohibition of discrimination in the workplace. Some legislation also includes proactive provisions to foster respect for human rights in business.

In addition to the above two foundational principles, NAP lists many other principles within the chapter on the state's duty to protect human rights. Among them, two principles seem to be particularly relevant for situations in Slovenia where the state is heavily involved in the ownership and management structure of the private sector. Principles 3.d and 4 together constitute the cornerstones for analyzing the role of the state-owned business enterprises in respecting and protecting human rights.

Principle 3.d provides that states should encourage and where appropriate require business enterprises to communicate how they address their human rights impacts. ${ }^{5}$ There are two primary tools for enterprises to communicate this issue.

The first tool concerns non-financial reporting. For instance, Directive 2014/95/EU of the European Parliament and of the Council of 22 October 2014 amending Directive 2013/34/EU as regards disclosure of nonfinancial and diversity information by certain large undertakings and groups ${ }^{6}$ requires that large companies disclose certain information on the methods they employ to operate and manage social and environmental challenges. Nonfinancial reporting provides investors and other interested parties with a more complete picture of the development, efficiency, status and environmental and social impacts of companies' activities. Slovenia incorporated the non-financial reporting obligation for large companies into its legal system by amending its Companies Act

\footnotetext{
${ }^{5}$ NAP, pp. $20-24$.

${ }^{6}$ OJ L 330, 15. 11. 2014, p. 1-9.
} 
in 2017.7 In accordance with the first paragraph of Article 70c of the Slovenian Companies Act, "all public-interest large companies whose average number of employees in a financial year exceeds 500 on the balance sheet date must include in its business report a statement of non-financial operations which, as far as is necessary to understand the development, performance and position of the company and the impact of its activities, contains information on", inter alia, respect for human rights.

The second primary tool for communication on matters pertaining to human rights is by exercising due diligence. NAP recommends that business enterprises based in Slovenia conduct human rights due diligence throughout the business process in order to guarantee human rights in business in accordance with the Guiding Principles. Furthermore, NAP recommends that business enterprises include due diligence reports in their annual reports or in sustainability reports. It is important to highlight the commitment of the Slovenian government to strive for development and to foster human rights due diligence in business operations with the special focus on state-owned enterprises. ${ }^{8}$

Principle 4 reads as follows:

"States should take additional steps to protect against human rights abuses by business enterprises that are owned or controlled by the state, or that receive substantial support and services from state agencies such as export credit agencies and official investment insurance or guarantee agencies, including, where appropriate, by requiring buman rights due diligence." 9

This principle highlights the special role of state-owned enterprises in protection against human rights abuses by business enterprises. In parallel with OECD Common Approaches for Officially Supported Export Credits and Environmental and Social Due Diligence, this principle recommends that officially supported credits approved by the export credit agencies take into account environmental issues, climate change, social and human rights, obligations to respect relevant international agreements and conventions and that they contribute to sustainable development.

\footnotetext{
${ }^{7}$ Official Gazette of the Republic of Slovenia, Nr. 15/17.

${ }^{8} \mathrm{NAP}, \mathrm{pp} .23-24$.

${ }^{9} \mathrm{NAP}$, p. 24.
} 
More is expected from state-owned enterprises in light of the state's role as the primary guarantor of human rights. This is entirely logical since it follows that the state should have more direct influence over subject matters that are most closely connected to its activities.

It can be argued that this principle recommends the positioning of state-owned enterprises as role models and leaders in protection against human rights abuses by businesses. The state should exercise its ownership functions in state-owned enterprises in a way to both establish and promote higher standards for protection against human rights abuses by businesses.

It should be noted that economic motives for respect for human rights are not necessarily prima facie obvious, therefore, it is reasonable to expect that - at least in the initial phase of asserting corporate responsibility for preventing human rights violations - the state as the owner is in a particularly prominent position to take a leadership role and to take proactive measures by, for example, providing adequate resources to prevent human rights violations throughout the whole business process.

\subsection{Access to remedies}

In the chapter relating to the question of access to remedies, NAP lists six principles. Principles $25^{10}$ and $26^{11}$ highlight the state's obligation to take appropriate steps to ensure access to effective remedies and to ensure the effectiveness of domestic judicial mechanisms when human right abuses by businesses occur. In addition to judicial mechanisms, states should - as recommended by the principle $27^{12}$ - provide effective and appropriate non-judicial grievance mechanisms to remedy businessrelated human rights abuses.

\footnotetext{
${ }^{10}$ Principle 25 reads as follows: "As part of their duty to protect against business-related buman rights abuse, States must take appropriate steps to ensure, through judicial, administrative, legislative or other appropriate means, that when such abuses occur within their territory and/ or jurisdiction those affected have access to effective remedy."

11 Principle 26 reads as follows: "States should take appropriate steps to ensure the effectiveness of domestic judicial mechanisms when addressing business-related human rights abuses, including considering ways to reduce legal, practical and other relevant barriers that could lead to a denial of access to remedy."

12 Principle 27 reads as follows: "States should provide effective and appropriate non-judicial grievance mechanisms, alongside judicial mechanisms, as part of a comprehensive State-based system for the remedy of business-related human rights abuse."
} 
In this context it has to be noted that, in Slovenia, human rights and fundamental freedoms are incorporated into Chapter II of the Slovenian Constitution. ${ }^{13}$ Article 15 of the Constitution stipulates that human rights and fundamental freedoms shall be exercised directly on the basis of the Constitution. The manner in which human rights and fundamental freedoms are exercised may be regulated by law whenever the Constitution so provides or where this is necessary due to the particular nature of an individual right or freedom. No human right or fundamental freedom regulated by legal acts in force in Slovenia may be restricted on the grounds that this Constitution does not recognise that right or freedom or recognises it to a lesser extent.

Principles $28,{ }^{14} 30^{15}$ and $31^{16}$ generally suggest that the state should strive to improve appeal mechanisms related to violations of human rights in business, especially by enhancing effectiveness, accessibility, predictability and transparency of procedures. These principles provide that the Slovenian state must continue its efforts to strengthen cooperation with all relevant stakeholders, in particular nongovernmental organisations (hereinafter: NGOs), businesses, trade unions and academia, in order to encourage business enterprises to develop and apply relevant appeal mechanisms to address the alleged or potential violations of human rights in business processes. ${ }^{17}$

\subsection{Slovenia's priorities}

Whereas it is true that business enterprises ensure respect for human rights by fully complying with the laws, the NAP takes literal compliance with the law one step further by encouraging business enterprises to be proactive and to do more than is required as a minimum standard and stipulated by hard laws.

\footnotetext{
${ }_{13}$ Official Gazette of the Republic of Slovenia, Nos. 33/91-I, 42/97, 66/00, 24/03, 69/04, 68/06, 47/13 and 75/16.

14 Principle 28 reads as follows: "States should consider ways to facilitate access to effective non-State-based grievance mechanisms dealing with business-related human rights harms.«

${ }_{15}$ Principle 30 reads as follows: „Industry, multi-stakeholder and other collaborative initiatives that are based on respect for human rights-related standards should ensure that effective grievance mechanisms are available.«

${ }_{16}$ Principle 31 reads as follows: »In order to ensure their effectiveness, non-judicial grievance mechanisms, both State-based and nonState-based, should be: legitimate, accessible, predictable, equitable, transparent, rights-compatible and a source of continuous learning. Operational-level mechanisms should also be based on engagement and dialogue: consulting the stakeholder groups for whose use they are intended on their design and performance, and focusing on dialogue as the means to address and resolve grievances." ${ }^{17}$ NAP p. 41.
} 
The NAP identifies that the most common human rights violations in business relate to discrimination, abuses in the workplace, and negative environmental impacts. With respect to discrimination, it has to be noted that in the Mangold case, ${ }^{18}$ the Court of Justice of the EU (CJEU) declared that the principle of non-discrimination (on the grounds of age) is a general principle in EU law and, furthermore, has a direct effect (Craig and de Búrca, 2015: 186). However, non-discrimination as a general principle has been guaranteed also by the Article 21 of the Charter of Fundamental Rights of the European Union. ${ }^{19}$ Non-discrimination or equal treatment is - as is the case with all other general principles of EU law - a component of the primary EU legislation (Craig and de Búrca, 2015: 932). Although this principle has evolved over time from the protection of equal treatment of men and women, the principle has gradually expanded into other areas as well and, presently, all EU laws and measures must be read in the light of the principle of equal treatment. ${ }^{20}$ Since nondiscrimination is a general principle of EU law, its content is coincident in all situations. In essence, this principle dictates that comparable situations must not be treated in disparate fashions, and different situations must all not be treated in the same way, unless such treatment is objectively justified. It follows that discrimination is not forbidden per se. Infringement of the principle of non-discrimination is committed only when discrimination is not objectively justified. In other words, prohibiting discrimination as one of Slovenia's priorities requires a thoughtful, balanced approach. The approach should be vigorous and careful in order to sanction unjustified discrimination but, at the same time, must take adequate precaution so as not to hinder free economic initiative, as this freedom is guaranteed by the Article 74 of the Constitution. Further, care must be taken not to unproportionally restrict freedom to contract.

Building on the identified areas where most common human rights violations in Slovenia business occur (i.e. discrimination, abuses in the workplace, and negative environmental impacts), the NAP established the following five priorities for human rights protection in the business sector. First, the prevention of discrimination and inequality as well as the promotion of equal opportunities. Second, the promotion and protection of fundamental workers' rights, not only in in transnational businesses but also along the entire production chain. Third, the prevention of, and

\footnotetext{
${ }^{18}$ Case C-144/04, Magnold v Rüdiger Helm, ECLI:EU:C:2005:709.

${ }^{19}$ OJ C 326, 26. 10. 2012, p. 391-407.

${ }^{20}$ Case C-401/11, Blanka Soukupová v Ministerstvo zemědělství, ECLI:EU:C:2013:223.
} 
fight against, trafficking in human beings. Fourth, environmental protection, nature conservation, and sustainable development. Fifth, human rights due diligence. ${ }^{21}$ The latter priority is specially emphasized in the NAP since its annex provides detailed guidelines on corporate human rights due diligence.

\subsection{Slovenia's expectations towards business enterprise}

The fundamental expectation of the Slovenian state toward business enterprises that are established under Slovenian law or that carry on their activities in Slovenia is that they comply with the laws and Slovenian Constitution and thus protect human rights. Human rights and fundamental freedoms are exercised directly on the basis of the Constitution. The second chapter of the Constitution defines not only the obligations of the state but also of enterprises registered or operating in Slovenia. In addition, business enterprises also are encouraged to comply with the Guiding Principles, the OECD Guidelines for Multinational Enterprises, and the ILO Tripartite Declaration of Principles concerning Multinational Enterprises and Social Policy, and to report according to ISO 26000 and GRI standards. With the NAP, Slovenia further expects business enterprises to establish appropriate mechanisms for human rights due diligence. ${ }^{22}$

\section{Corporate human rights due diligence in Guiding Principles and in NAP Guidelines}

\subsection{What it is and why does it matter}

Business enterprises, on the one hand, have an obligation not to actively infringe upon human rights through their conduct (negative obligation) and, on the other hand, are encouraged to actively take preventive measures. The responsibility of business enterprises to respect human rights must be viewed from two separate perspectives. First, they must actively avoid causing or contributing to adverse human rights impacts through their own activities, but must properly address such impacts when they do occur, Secondly, even if they have not directly contributed to those impacts, business enterprises still must take steps to prevent or mitigate

\footnotetext{
${ }^{21}$ NAP, p. 6.

${ }^{22}$ NAP, p. 6-8.
} 
adverse human rights impacts that are directly linked to their operations, products or services by their business relationships (Ruggie, 2011: 5).

Human rights due diligence should be understood as a positive obligation on the part of business enterprises that requires them to strive at all times to manage and supervise their operations and their supply chains so as to help minimize if not entirely prevent violations from occurring (Letnar Černič, 2018: 113). Furthermore, in the case of the inevitable human rights violations by business enterprises that will occur, state-based, non-judicial mechanisms for accountability and remedy for business-related human rights abuses need to be established. Virtually all jurisdictions recognize the value of state-based, non-judicial mechanisms as a means of helping to resolve complaints and disputes arising from adverse human rights impacts of business activities. ${ }^{23}$

The Guiding Principles clarify that all business enterprises, regardless of their size, ownership or other characteristics, have an independent responsibility to respect human rights. Business enterprises should avoid infringing on the human rights of others and should address adverse human rights impacts when they occur. ${ }^{24}$ Human rights due diligence is a core constituent element of the recommended proactive business enterprises' approach for respecting human rights. Indeed, it is beyond doubt that human rights due diligence comprises an ongoing management process that a reasonable and prudent enterprise needs to undertake to meet its responsibility to respect human rights. ${ }^{25}$

It has to be noted that the Guiding Principles differentiate between states' duty to protect human rights and business enterprises' responsibility to respect human rights. Deriving from the general principles of the Guiding Principles, states are obliged to respect, protect and fulfil human rights and fundamental freedoms, whereas business enterprises, as specialized organs of society performing specialized functions, are required not only to comply with all applicable laws but to respect human rights. However, business enterprises' responsibility to respect human rights

\footnotetext{
${ }^{23}$ Discussion paper, Accountability and Remedy Project Part II: State-based non-judicial mechanisms, State-based non-judicial mechanisms for accountability and remedy for business-related human rights abuses: Supporting actors or lead players? (Nov. 2, 2017), p. 8, Human Rights Office of the High Commissioner.

${ }^{24}$ Guiding Principles, principle 11.

25 The Corporate Responsibility to Respect Human Rights, An Interpretive Guide, United Nations Human Rights Office of the High Commissioner, p. 6.
} 
should not be interpreted as a passive or somehow meek obligation to do no harm. Quite the opposite, this responsibility requires a proactive approach to seek out, identify and then prevent their potential or actual harmful impacts on human rights. Preventing and addressing adverse impacts on human right through comprehensive and appropriate human rights due diligence is the most significant contribution most business enterprises can make towards sustainable development. ${ }^{26}$

The Guiding Principles define human rights due diligence as a "/.../process to identify, prevent, mitigate and account for how... [business enterprises] address their impacts on human rights". ${ }^{27}$ In other words, business enterprises have an independent responsibility to respect human rights, and in order to do so they are required to exercise human rights due diligence. Human rights due diligence includes the following elements: assessment of actual and potential human rights impacts, integration and implementation of the findings, tracking responses and, finally, reporting. The Guiding Principles explain that in order to mitigate human rights risks it is recommended that human rights due diligence should be initiated as early as possible in the development of a new activity. ${ }^{28}$

A similar due diligence concept - that is an instrument to identify, prevent or mitigate and account for how actual and potential adverse impacts are addressed by the enterprises - is recommended not only by the Guiding Principles but also by the OECD Due Diligence Guidance for Responsible Business Conduct and ILO Tripartite Declaration of Principles Concerning Multinational Enterprises and Social Policy. However, none of these quasi-legal documents impose binding obligations on business enterprises to conduct due diligence. Interestingly, important legal developments at the national levels can be identified. France, for example, was the first country to adopt mandatory human rights due diligence for some companies and general liability principles in case of harm. The French Corporate Duty of Vigilance Law entered into force in $2017 .{ }^{29}$ Furthermore, at the EU level significant changes are expected. In April 2020, Commissioner for Justice Didier Reynders

\footnotetext{
${ }^{26}$ Working Group on the issue of human rights and transnational corporations and other business enterprises, A/73/163, 16 July 2018, p. 6

${ }_{27}$ Guiding Principles, principle 15b.

${ }^{28}$ Guiding Principles, p. 18.

${ }^{29}$ Journal Officiel de la République Française [J.O.] [Official Gazette of France], March 27, 2017.
} 
announced that the Commission will introduce a legislative initiative in 2021 on mandatory due diligence for companies. ${ }^{30}$

\subsection{Good practices}

The Working Group has identified the following emerging good practices for conducting human rights due diligence: stakeholder engagement (3.2.1.), transparency and meaningful reporting (3.2.2.), managing the risks to and impacts on human rights beyond tier one (3.2.3.), building and exercising leverage in business relationships to end and mitigate human rights abuse (3.2.4.), addressing systemic issues (3.2.5.), and using human rights due diligence as an entry point for contributing to the United Nations Sustainable Development Goals (3.2.6.). ${ }^{31}$

\subsubsection{Stakeholder engagement}

Stakeholder engagement should not be understood as a one-way process of providing information to the stakeholders but rather as a two-way process which includes direct engagement with affected stakeholders. However, direct dialogue with affected stakeholders is not always possible. Therefore, engagement of proxies and/or other stakeholders, e. g. ombudsman, trade unions, NGOs, etc. is a very useful and fruitful way for identifying the potential risks to human rights as well as for addressing potential and actual impacts of the business enterprise on human rights. Furthermore, promoting formal and permanent partnerships and collaboration with human rights NGOs can improve identification of potential and actual adverse impacts of the business enterprises on the human rights. ${ }^{32}$

\footnotetext{
30 Announcement has been made during the webinar hosted by the European Parliament's Responsible Business Conduct Working Group. Webinar is accessible at this link

https:// responsiblebusinessconduct.eu/wp/2020/04/30/european-commission-promises-mandatory-duediligence-legislation-in-2021/.

31 Companion note II to the Working Group's 2018 report to the General Assembly (A/73/163), United Nations Working Group on Business and Human Rights, Corporate human rights due diligence - Getting started, emerging practices, tools and resources, October 16, 2018, accessible at this link https://www.ohchr.org/Documents/Issues/Business/Session18/CompanionNote2DiligenceReport.pdf. ${ }^{32}$ Ibidem, pp. 10-11.
} 


\subsubsection{Transparency and meaningful reporting}

Transparency and meaningful reporting require clear and publicly available human rights impact assessments for particular projects or operations. Furthermore, this reporting requires accurate descriptions of the due diligence processes that the business enterprise has in place to address specific risks. Two of the possible indicators of the emerging good practices are the following. First, that adequate resources are being devoted to identifying risks to human rights. Second, it also is necessary for business enterprises having affiliated companies and business partners to jointly commit to implement Guiding Principles. ${ }^{33}$

\subsubsection{Managing the risks to and impacts on human rights beyond tier one}

Managing the risks to and impacts on human rights beyond tier one requires business enterprises to manage the risks and impacts in all tiers of its value chain. An example of a good practice for going beyond tier one is that a business enterprise imposes requirements on the direct suppliers as well as its suppliers further down the value chain or, for instance, to identify critical points in the value chain where human rights violations are most likely to occur, and focus on them. However, in cases where the supply chain is comprised of a number of operations that are carried out by a number of suppliers and several tiers, a collective approach is more viable since enterprises in the same branch often have the same suppliers. ${ }^{34}$

\subsubsection{Building and exercising leverage in business relationships to end and mitigate human rights abuse}

Building and exercising leverage in business relationships as a part of human rights due diligence can be exercised in two general ways, namely through contracts with business partners and through unilateral or collective engagement of the business enterprise. The latter should clearly state its expectation that all business partners respect human rights. In case they do not respect human rights, the business relationship(s) needs to be terminated. ${ }^{35}$

\footnotetext{
33 Ibidem, pp. 12-13.

34 Ibidem, pp. 13-15.

35 Ibidem, pp. 15-16.
} 


\subsubsection{Addressing systemic issues}

Business enterprises should address systemic issues and root causes. It does not seem reasonable to expect that business enterprises are capable of addressing and preventing all human rights violations. However, that fact alone should not dampen high expectations and the enthusiasm to prevent such violations and business enterprises should certainly strive to do so within the realm of their realistic abilities. ${ }^{36}$

\subsubsection{Using human rights due diligence as an entry point for contributing to the Sustainable Development Goals}

Human rights due diligence is as an entry point for contributing to the Sustainable Development Goals as robust human rights due diligence enables and contributes to sustainable development. It has to be emphasized that business strategies that contribute to the Sustainable Development Goals are not to be taken as a substitute for human rights due diligence. The most powerful contribution of business enterprises to sustainable development is to respect human rights in all their activities. $^{37}$

\subsection{Government actions as drivers of corporate human rights due diligence}

States have a duty to protect human rights and there are many levers that can be used to effectuate this duty. Furthermore, the Working Group has highlighted that one $^{38}$ of the most important drivers of corporate human rights due diligence is pressure from the government. ${ }^{39}$ Human rights due diligence incentives can be given particularly through legislation and/or through state-owned enterprises. The latter approach is of great importance for states with considerable amounts of states'

\footnotetext{
${ }^{36}$ Ibidem, p. 16-18.

37 Ibidem, p. 18-19.

${ }^{38}$ In addition to the governments' pressures, the Working Group has identified investors' pressures as an important driver of corporate human rights due diligence as well. Investors' influence manifests in their expectations that business enterprise in which they invest manages all risks properly and carries out appropriate human rights due diligence. The latter has been recognized as a mean to improve risk management overall.

${ }^{39}$ The Report of the Working Group on the issue of human rights and transnational corporations and other business enterprises, Working Group on the issue of human rights and transnational corporations and other business enterprises, A/73/163, 16 July 2018, p. 16-24.
} 
capital investments in business enterprises. In such environments, states are significant economic actors and trendsetters and mainstream businesses will most likely follow the approach of the state-owned enterprises towards respecting human rights and conducting human rights due diligence. The special role of the stateowned enterprises is also expected in accordance with the previously mentioned Guiding Principle 4.

State-owned enterprises should be trendsetters and should lead by example in respecting human rights and in conducting appropriate, meaningful and systemic reporting and human rights due diligence. Governments should express their legitimate expectation that state-owned enterprises not only conduct human rights due diligence but also that they require the same from their suppliers and other business partners. States should leverage their role as economic actors to promote corporate human rights due diligence as standard and expected business conduct.

\subsection{NAP Guidelines on corporate human rights due diligence}

In order to provide meaningful reporting on respecting human rights, business enterprises should focus on those human rights which are most likely to be violated in their value chain and not only on those which are most notorious and mediaexposed. Building on this premise, the NAP provides guidelines for implementing corporate human rights due diligence by recommending the following five-step process. ${ }^{40}$ First, to make a commitment to respect human rights (3.4.1.). Second, to establish a structure for due diligence (3.4.2.). Third, to identify relevant facts (3.4.3.). Fourth, to implement human rights risk management (3.4.4.). Fifth, to exercise transparency relative to the business enterprise's observance of human rights (3.4.5.).

\subsubsection{Commitment to respect human rights}

The clear and unconditional commitment on the part of the business enterprise to respect human rights is the first step that must be taken by the business enterprise in order to implement the human rights due diligence. This commitment should be

${ }^{40}$ NAP, Annex I, pp. 44-47. 
included into the business enterprise's values, codes and risk management. Adequate resources must be devoted to achieve the commitment to respect human rights. ${ }^{41}$

\subsubsection{Establish a structure for due diligence}

Establishing a structure for due diligence requires, first, the designation of the officer responsible for carrying out all internal processes relevant for respecting human rights, and, second, deciding whether human rights due diligence is to be conducted internally, externally or with some combination of both resources. ${ }^{42}$

\subsubsection{Identification of relevant facts}

Identification of relevant facts is a prerequisite for preventing or minimising risks of disrespect of human rights. These relevant facts must be identified throughout the entire value chain. In addition to the business process of the enterprise, this includes also procurements, suppliers, production and sales activities. However, since the process of identification of relevant facts might be very complex in cases where business enterprises conduct business in many states and have many subsidiaries, affiliated companies and business partners, it is important to generate a priority list of the potentially most critical human rights. ${ }^{43}$

\subsubsection{Implementation of human rights risk management}

Implementation of human rights risk management requires the business enterprise to establish the following four mechanisms. First, a mechanism for detecting human right violations; second, a mechanism for ensuring a proper response in case of identified violations; third, a mechanism for compensating damages and for reimbursement in case of disrespect for human rights; and fourth, a mechanism for promoting respect for human right by all business partners. ${ }^{44}$

\footnotetext{
41 Ibidem, p. 44.

42 Ibidem, p. 45.

${ }^{43}$ Ibidem.

${ }^{44}$ Ibidem, pp. 45-46.
} 


\subsubsection{Transparency}

Transparency about the business enterprise's observance of human rights requires the business enterprise to report regularly and clearly, for instance in its annual report or in special reports on non-financial aspects of its business operations (e.g. sustainability report or corporate social responsibility report). In order to provide comparability of reporting, business enterprises can draw from some of the already well-established international standards and initiatives that developed basic indicators for monitoring human rights, e.g. EU directive on non-financial reporting for public-interest companies with more than 500 employees (transposed to Slovenian legal order with the Act Amending the Companies Act), GRI guidelines on reporting on sustainability in business operations, ISO 26000 - social responsibility guidelines for enterprises, SA 8000 Certificate, and Principles of the United Nations Global Compact. ${ }^{45}$

\section{Implementation of the Guiding Principles in the business practice of Slovenian state-owned enterprises}

\subsection{Slovenian state as an owner}

The Republic of Slovenia has capital investments in a number of companies, including all nine public limited companies listed in the Prime Market of the Ljubljana Stock Exchange, namely logistics company Intereuropa; pharmaceutical company Krka; port operator Luka Koper; retailer Poslovni sistem Mercator; bank Nova Ljubljanska banka; energy distributer Petrol; reinsurance company Pozavarovalnica Sava; telecommunications operator Telekom Slovenije; and, insurance company Zavarovalnica Triglav. ${ }^{46}$ Such an extensive involvement of the Slovenian state into the ownership structures of the Slovenian companies significantly increases the state's responsibility for protection of human right in the business enterprises. The stronger the state's influence on the business enterprises is, the greater is the state's responsibility for their actions, including their compliance with human rights.

\footnotetext{
45 Ibidem, p. 46.

46 As of 30 April 2020, Republic of Slovenia hold capital investments in 93 companies [https://www.sdh.si/slsi/upravljanje-nalozb/seznam-nalozb] (accessed: 31. 5. 2020).
} 
The state acts in two capacities, ex iure imperii (acting in the capacity of public authority) and ex iure gestionis (acting in the commercial, civil capacity). In the former capacity, the state is required to, inter alia, establish an appropriate normative framework for the protection of human rights in business enterprises and to penalise effectively all contraventions of the normative framework. In the latter capacity, the state exercises its shareholder's right deriving from its ownership of capital investments. Thus, the state as a shareholder is best situated to lead by example and to implement all recommendations, best practices and other soft-law in all "its" business enterprises. If state-owned enterprises do not follow the state's soft laws regarding human rights in business, such non-compliance undermines the soft laws' authority and questions not only the state's credibility as an owner but also the appropriateness of soft laws. This in particular relates to the situation where, as is the case of Slovenia, the state is heavily involved in the ownership structure of companies.

\subsection{Commitment to respect human right in business and to prevent possible negative impacts on human rights}

The Slovenian Sovereign Holding Act (hereinafter: SSHA-1) is an organic law that regulates the management of the Slovenian capital investments. One of the purposes of the SSHA-1 is to ensure proper management of the state's assets in compliance with both Slovenian and international guidelines of good practice of the management of assets of the state and corporate governance in general. ${ }^{47}$ In order to separate the state's ownership functions from its other functions, and in order to improve and concentrate management of the assets owned by the state, the Republic of Slovenia has established the Slovenian Sovereign Holding (hereinafter: SSH) as a public limited company. In other words, the Slovenian state plays a significant ownership role in Slovenian companies and SSH is the key state institution for exercising its shareholders' rights.

In 2019, SSH signed a commitment to respect human right in business and to prevent possible negative impacts on human rights. Furthermore, SSH clearly expressed its intention to encourage all portfolio companies to accede to the commitment to respect human rights in business as state-owned companies must

\footnotetext{
${ }^{47}$ Article 1(2), fourth indent, of SSHA-1.
} 
set an example to all other companies in this field. ${ }^{48}$ Commitment to respect human rights in business has been prepared and promoted by the Slovenian government and is based on several instruments. These instruments include the Universal Declaration of Human Rights, adopted by the UN General Assembly in 1948, and other relevant international human rights instruments, as well as international instruments in the field of protection and promotion of human rights in economic activities, starting with the most authoritative document, the Guiding Principles and other key documents, e.g. OECD Guidelines for Multinational Societies, the Tripartite Declaration of the International Labor Organization on Multinational Enterprises and Social Policy, and the Guidelines on Social Responsibility (ISO 26000, GRI). At the national level, area of human right in business is regulated by the NAP as described in the previous chapters.

By signing the Commitment, companies commit to respect human rights in the entire business process and to avoid and prevent possible negative impacts on human rights. The Commitment comprises seven fundamental principles. First, respect for human rights shall be placed among the values or fundamental principles of the company, as well as in the code of ethics and other relevant internal documents in a way that will ensure their identification and their operational implementation in all business processes. Second, companies shall appoint a human rights trustee to monitor and supervise all activities pertaining to respect for human rights, and to organize training and establish a mechanism to deal with violations. In addition to the appointment of a human rights trustee, companies shall also educate managers and responsible persons regarding all aspects of the Commitment. Third, a company commits to conduct a due diligence in order to identify key risk factors for human rights violations in all business processes. Due diligence shall become a part of the company's risk management system and, in accordance with the findings thereof, the company shall establish a mechanism(s) for responding not only to identified failures to respect human rights but also for mitigating the consequences of non-compliance with human rights. Fourth, respect for human rights shall be regularly monitored and reported findings reported upon in an annual or sustainability report. Fifth, companies shall raise awareness and educate employees and other stakeholders about human rights and business. Moreover, companies shall

\footnotetext{
${ }^{48}$ Statement of the CEO of SSH given on an occasion of formal signature of commitment to respect human rights in business (https://www.sdh.si/sl-si/novice/1741/sdh-podpisal-zavezo-k-spostovanju-clovekovih-pravic-priposlovanju; accessed: 31.5 .2020 ).
} 
establish an internal grievance mechanism that will be available and presented to employees and other stakeholders. Sixth, companies shall promote respect for human rights among business partners. Seventh, companies shall proactively seek out common solutions and cooperate with key stakeholders with the aim of making progress in respecting human rights in business. It has to be noted that signatories of the Commitment have thereby agreed to carry out all of the above-described measures gradually but not later than within the period of three years from the signatory date, that is until 31 May 2022. At the moment, there is no clear evidence how many of the signatories have already carried out measures to fulfil commitments.

In addition to the above-described Commitment, $\mathrm{SSH}$ has carried out other initiatives aiming at respect for human right in business as well. In 2014, SSH adopted the Corporate Governance Code for State-Owned Enterprises and lastly amended it in 2019. Inter alia, it recommends to state-owned enterprises and its subsidiaries to adopt a Code of Ethics which should include the company's respect for human rights, both in regard to the recruitment and in relation to employees. ${ }^{49}$

\subsection{Way forward}

Since state-owned companies play particularly important roles in respecting human rights in business, it cannot be ignored that ten out of a total of twelve companies that have signed the Commitment to respect human rights are companies with state's capital investment. One could argue that this is a clear signal that the state, as an owner of capital investments, leads by example and is proactive not only in its ex iure imperii capacity but also in its ex iure gestionis capacity. Undoubtedly, a significant majority of the companies that have signed a Commitment are companies with the state's portfolio. However, there are two sides to every coin. Although it is true that companies with the state's capital investments constitute the vast majority of the signatories of the Commitment, it also is the case that a significant number of state companies have not signed the Commitment yet. In fact, 83 companies out of a total of 93 companies within the state's portfolio have not committed to respect human right by signing the Commitment. Since signature to the Commitment has - at least

\footnotetext{
${ }^{49}$ Recommendation 10.1.1. of the Corporate Governance Code for State-Owned Enterprises.
} 
- strong symbolic meaning, ${ }^{50}$ it is crucial that all companies in which the state has a capital stake, accede to the Commitment. This would greatly strengthen the message that the commitment to respect for human rights must become the standard in the operations of all companies established and operating in the Republic of Slovenia. It seems inconceivable that any Slovenian company - especially ones by the state's capital investment - would deny responsibility to respect something as universally accepted and fundamental as human rights at the declaratory level (Rozman, 2020: 9-11).

\section{$5 \quad$ Conclusion}

As indicated in the introduction of this paper, and as argued by other academics (Letnar Černič, 2018: 101-116), ${ }^{51}$ there presently is a lack of binding international legal acts imposing direct obligations on the business enterprises to protect human rights. At the international level, there are currently only soft law documents concerning corporate human rights obligations. Therefore, one of the approaches that can and should be taken by states which are firmly committed to proactively protecting and respecting human rights is to enhance the protection of human rights primarily at the domestic levels. Each process must start somewhere. The commitment on the part of all state-owned enterprises to respect human rights seems to be both a rational and logical starting point.

From the point of view of safeguarding and defending human rights, it would be desirable to follow the example of the recent French law and establish mandatory corporate human rights due diligence for - at a minimum - large and medium sized enterprises. This approach would be consistent with the announcement of the European Commission to introduce a legislative initiative on mandatory due diligence for companies in 2021. The combination of domestic binding and legally enforceable laws on mandatory corporate human rights due diligence and soft law recommendations seem to be the so called "smart mix" (Methven O'Brien, 2019: 22-24) that would raise the currently expected business conduct in the field of protecting human rights by business enterprises in a gradual, feasible and realistic

\footnotetext{
${ }^{50}$ The practical meaning depends on the implementation of principles and commitments in the operations of companies.

${ }^{51}$ See also: Report of the Working Group on the Issue of Human Rights and Transnational Corporations and Other Business Enterprises, paras 75-78, 86, U.N. Doc. A/72/162 (July 18, 2017).
} 
manner. Until adoption of such law, companies with state's capital investments should lead by example and, as is the case in Slovenia, sign a Commitment and take additional steps to signal to other companies that respecting human rights and conducting corporate human rights due diligence have become expected conduct. Nevertheless, taking into account the recent European Commission announcement, such conduct would be in accordance with de lege ferenda.

\section{Acknowledgement:}

The author acknowledges that the project "Holistic approach to business and human rights: a normative reform of Slovenian and international legal order (no. JP-1790)" was financially supported by the Slovenian Research Agency."

\section{References}

Bernaz, N. (2018) The Draft UN Treaty on Business and Human Rights: The Triumph of Realism over Idealism, Business \& Human Rights Resource Centre, https://www.businesshumanrights.org/en/the-draft-un-treaty-on-business-and-human-rights-the-triumph-ofrealism-over-idealism (accessed: 31. 5. 2020).

Corporate Governance Code for State-Owned Enterprises (2019) Slovenian Sovereign Holding, https://www.sdh.si/Data/Documents/pravniakti/Kodeks\%20korporativnega\%20upravljanja_november\%202019_oblikovan.pdf.

Craig, P, and de Búrca, G. (2015) EU Law (Oxford: Oxford University Press).

Discussion paper, Accountability and Remedy Project Part II: State-based non-judicial mechanisms, State-based non-judicial mechanisms for accountability and remedy for business-related human rights abuses: Supporting actors or lead players? (Nov. 2, 2017), Human Rights Office of the High Commissioner.

Guiding Principles on Business and Human Rights: Implementing the United Nations "Protect, Respect and Remedy" Framework (2011) United Nations Human Rights office of the high commissioner,

https://www.ohchr.org/documents/publications/guidingprinciplesbusinesshr_en.pdf (accessed: 31. 5. 2020).

Letnar Černič, J. (2018) Moving Towards Protecting Human Rights in Global Business Supply Chains, Boston University international law journal, 36(2), pp. 101-115.

Methven O’Brien, C. (2019) EU Business and Human Rights Policy: Still More 'Invisible Hand' than 'Smart Mix', Perspectives Paper Business and Human Rights - Towards a Common Agenda for Action, Finnish Government, pp. 22-24.

Nacionalni akcijski načrt Republike Slovenije za spoštovanje človekovih pravic v gospodarstvu (2018) Vlada Republike Slovenije, https://www.gov.si/assets/ministrstva/MZZ/Dokumenti/multilaterala/clovekovepravice/ac538a252d/Nacionalni_akcijski_nacrt_RS_za_spostovanje_clovekovih_pravic_v_g ospodarstvu.pdf (accessed: 31. 5. 2020).

Report of the Working Group on the Issue of Human Rights and Transnational Corporations and Other Business Enterprises, U.N. Doc. A/72/162 (July 18, 2017).

Rozman, T. (2020) Vodilna vloga podjetij s kapitalsko naložbo države pri promociji in spoštovanju človekovih pravic v gospodarstvu, Slovenski državni holding, d. d., in spoštovanje človekovih pravic v gospodarstvu (Ed. Letnar Černič, J.), Nova Univerza, Fakulteta za državne in evropske študije, pp. 9-11. 
Ruggie, J. (2011) Report on the Issue of Human Rights and Transnational Corporations and Other Business Enterprises - Guiding Principles on Business and Human Rights: Implementing the United Nations "Protect, Respect and Remedy" Framework.

The Corporate Responsibility to Respect Human Rights, An Interpretive Guide (2012) United Nations Human Rights Office of the High Commissioner https://www.ohchr.org/Documents/publications/hr.puB.12.2_en.pdf (accessed: 31. 5. 2020). The Report of the Working Group on the issue of human rights and transnational corporations and other business enterprises, Working Group on the issue of human rights and transnational corporations and other business enterprises, A/73/163, 16 July 2018, https://digitallibrary.un.org/record/1639520 (accessed: 31. 5. 2020).

\section{About the author}

\section{dr. Til Rozman}

is an Assistant Professor at the Faculty of Social Sciences, University of Ljubljana, Slovenia. 